\section{FUNCTIONAL BIGNAY CIDERS INHIBIT KEY ENZYMES LINKED TO OBESITY AND DIABETES FOR METABOLIC SYNDROME PROTECTION}

Jennifer Lhemana, Anthony Sutionob, Yantia,c*, Raymond Rubianto Tjandrawinataa,c, Bibiana Widiyati Laya,c

aMaster of Biotechnology, Atma Jaya Catholic University of Indonesia, 12930, Jakarta, Indonesia

bDepartment of Food Technology, Atma Jaya Catholic University of Indonesia, 12930, Jakarta, Indonesia

cResearch Center for Indonesian Spices, Atma Jaya Catholic University of Indonesia, 12930, Jakarta, Indonesia
Article history

Received

18 April 2020

Received in revised form

7 January 2021

Accepted

12 January 2021

Published online

23 February 2021

*Corresponding author yanti@atmajaya.ac.id

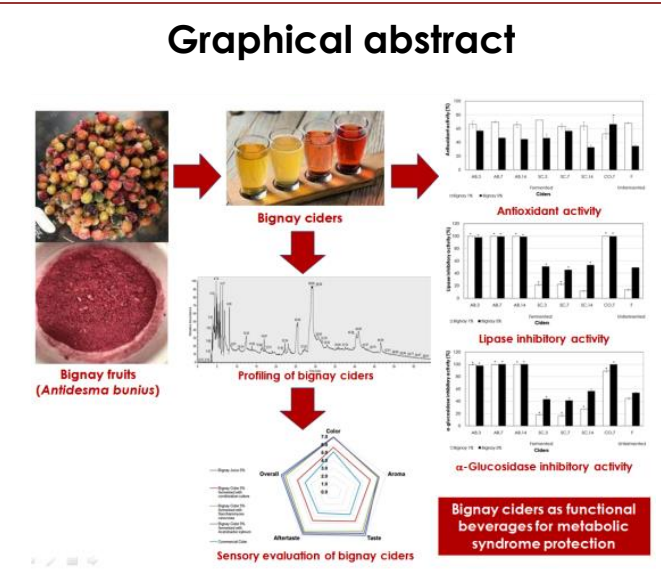

\begin{abstract}
Metabolic syndrome has become one of the major health issues worldwide. Cider beverages have several functional properties for health, such as antioxidant, antimicrobial, anti-inflammatory, and antidiabetic effects. In this study, we formulated cider beverages from bignay fruits (Antidesma bunius), identified their compounds, and evaluated their functional effects for metabolic syndrome protection. Ciders were produced from the aqueous extract of bignay fruit powder, fermented using Saccharomyces cerevisiae and Acetobacter xylinum for 3, 7, and 14 days. Compound identification in bignay ciders was done using gas chromatography-mass spectrometry (GC/MS). Antioxidant activity was done by the 1,1-diphenyl-2-picrylhydrazyl assay, while enzymatic inhibitory assays were tested against lipase, aglucosidase, a-amylase, and angiotensin converting enzyme (ACE). GC/MS profiling showed that most bignay ciders contained major organic acids and amino acids. All ciders exerted high antioxidant activity (>60\%). Bignay ciders fermented from A. xylinum demonstrated significant inhibition (>90\%) against lipase and a-glucosidase activities. However, ciders had no functional effect on $\alpha$-amylase and angiotensin-converting enzyme inhibition. These data suggest that bignay ciders may have potential as functional beverages with antioxidant, antiobesity, and antidiabetic effects for management of metabolic syndrome.
\end{abstract}

Keywords: Functional bignay ciders, Antidesma bunius, antioxidant activity, antiobesity activity, antidiabetic activity

(C) 2021 Penerbit UTM Press. All rights reserved

\subsection{INTRODUCTION}

Metabolic syndrome has become one of the major health issues worldwide. The cause of this syndrome remains obscure. The International Diabetes Federation (IDF) defines the characteristics of metabolic syndrome as the presence of three or more of the following features: obesity, 
hyperglycemia, hypertension, low high-density lipoprotein (HDL) cholesterol levels, and/or hypertriglyceridemia [1]. This syndrome is a master of disguise since it can present in various ways according to the different components that constitute the syndrome.

Obesity is characterized by an increase in body weight that results in excessive fat accumulation [2]. According to World Health Organization (WHO), worldwide obesity has nearly tripled since 1975. Most of the world's population live in countries where overweight and obesity kills more people than underweight [3]. Besides obesity, type 2 diabetes mellitus also has been associated with metabolic syndrome that is characterized by defects in insulin secretion and a peripheral insulin resistance in adipose tissue and liver. This disease also contributes to high rates of mortality and morbidity [4]. The other classical feature of the metabolic syndrome is hypertension or high blood pressure. It has been reported that metabolic syndrome is present in up to one third of the hypertensive patients. It is also associated with visceral obesity and insulin resistance, which are the main pathophysiologic features underlying the metabolic syndrome [5].

Cider or vinegar are commonly used in food preparation, such as pickling and enhancing flavor. Although useful as food ingredient for flavor and functional properties, it also has potential health benefits. Several functional therapeutic properties of vinegar have been reported, such as antibacterial activity, blood pressure reduction, antioxidant activity, antidiabetic effect, prevention of cardiovascular disease, antitumor, and anti-obesity effects [6[. Bignay fruit (Antidesma bunius), known as buni in Indonesia, is a wild plant and belongs to the Euphorbiaceae family. It is naturally distributed in Southeast Asia and grown in every village in Indonesia where the fruits are marketed in bunches $[7,8]$. According to Castillo-Israel et al., the maturity of bignay fruits is grouped in 3 stages based on the size and color, including the unripe, half-ripe, and fully ripe stages [9]. The unripe fruits have green to yellow pale color with sour and bitter taste. While the half-ripe and fully ripe fruits have red to blackish color and sweet taste [10].

Bignay fruits contain major organic and phenolic acids, including lactic acid, acetic acid, gallic acid, caffeic acid, ellagic acid, and ascorbic acid that have been reported for its efficacy for management of type 2 diabetes. The fruits also have main phenolic compounds, such as procyanidin, cathechin, epicatechin, rutin, and resveratrol [7]. For antioxidant activity, the fully ripe fruits showed the highest activity compared to that of other fruit stages [7]. The fruits also contain rich nutritional components such as carbohydrates, sugars, organic acids, proteins, minerals and vitamins [11]. In traditional medicine, the fruits can cure various ailments from lack of appetite, indigestion, high blood pressure to diabetes [8].
Bignay fruit is a traditional healthy alcoholic juice drink and cooked with fish or other foods. Previous review on bignay fruit was focused on the extraction method, compound profiling, and pharmacological effects [12]. There is no report about food product formulation derived from bignay fruits as well as its pharmacological effects. Meanwhile, several studies have been conducted regarding the health benefits of cider and bignay fruits. However, there is still few information about the health benefits of cider for metabolic syndrome protection, including obesity, diabetes, and hypertension. Also, there is no report about the formulation of bignay cider and its functional efficacy. Based on these facts, we formulated a functional cider beverage made from bignay fruits by employing microbial fermentation. To confirm its traditional use for treatment of diabetes, hypertension, and other diseases, we also investigated about the efficacy of this bignay cider for management of metabolic syndrome-related diseases. Therefore, the objectives of this study were to formulate cider beverages made from bignay fruits, to do profiling compounds in ciders, and to investigate the functional effects of ciders for metabolic syndrome protection through antioxidant and enzymatic inhibitory activities against obesity, diabetes, and hypertension.

\subsection{METHODOLOGY}

\subsection{Sample Preparation and Cider Production}

Two kilograms of fresh bignay fruits were purchased from traditional market in Bogor, West Java province (Indonesia). Samples were separated and collected for the half-ripe and fully ripe fruit stages with red to blackish color. Samples were cleaned, blended, and freeze-dried for 5 days. The dried samples were pounded to obtain a fine powder with approximately 60 mesh particle size. Bignay ciders were produced according to Budak et al. with slight modification [6]. The ciders were grouped into three types, the first type of cider was fermented using Acetobacter xylinum culture, the second type was fermented using Saccharomyces cerevisiae culture, and the third type was fermented using the combination of $S$. cerevisiae and A. xylinum culture. Bignay powder was dissolved using distilled water with final concentration of $1 \%$ and $5 \%(\mathrm{w} / \mathrm{v})$. Sugar $(5 \% \mathrm{w} / \mathrm{v})$ was added to provide nutrients for the culture growth, taste, and aroma to the cider product. Then, it was inoculated according to the type of cider with A. xylinum $(10 \% \mathrm{v} / \mathrm{v})$ and $\mathrm{S}$. cerevisiae $(1 \% \mathrm{w} / \mathrm{v})$ then fermented for 3, 7, and 14 days. Cider with combination culture was first fermented with $S$. cerevisiae $(1 \% \mathrm{w} / \mathrm{v})$ for 7 days, then followed by filtration. Sugar was added $(5 \% \mathrm{w} / \mathrm{v})$ and then fermented using A. xylinum (1:3) for another 7 days. After fermentation process, the ciders were filtered and stored for further analysis. 


\subsection{Measurement of $\mathrm{pH}$ and Alchohol Content}

The $\mathrm{pH}$ of the ciders was measured using $\mathrm{pH}$ meter. Alcohol content in ciders was determined using Conway dish based on the modified method of Kaye [13]. Alcohol was used as standard at various concentrations $10 \%, 0.08 \%, 0.16 \%, 0.24 \%, 0.32 \%$, and $0.40 \% \mathrm{v} / \mathrm{v})$. $\mathrm{Na}_{2} \mathrm{CO}_{3}$ and $\mathrm{Na}_{2} \mathrm{Cr}_{2} \mathrm{O}_{7}$ solution were used in this method according to Oktaviani et al. [14]. Samples were added with $1 \mathrm{ml}$ into the outer side of Conway dish and mixed with $1 \mathrm{ml} \mathrm{Na}_{2} \mathrm{CO}_{3}$ solution. Then $2 \mathrm{ml} \mathrm{Na}_{2} \mathrm{Cr}_{2} \mathrm{O}_{7}$ solution was added into the inner side of Conway dish and the dish was tightly closed. The dish was incubated $30^{\circ} \mathrm{C}$ for 1 hour. The $\mathrm{Na}_{2} \mathrm{Cr}_{2} \mathrm{O}_{7}$ solution was read at $605 \mathrm{~nm}$ using spectrophotometer (Thermo Scientific).

\subsection{Gas Chromatography-Mass Spectrometry Analysis}

Identification of chemical compounds in ciders was analyzed using gas chromatography-mass spectrometry (GC/MS) according to the method of Chinnici et al. [15]. GC/MS Trace 1310 (Thermo Scientific) was carried out to analyze the chemical compounds found in the sample. The samples were filtered using $0.22 \mu \mathrm{m}$ filter and a total of $10 \mu \mathrm{l}$ of the sample was injected to the capillary column TG-5MS (5\% diphenyl/95\% dimethyl polysiloxane) using the splitless mode (splitless time of $0.6 \mathrm{~min}$ ). Temperature start was $35^{\circ} \mathrm{C}$ heated $3^{\circ} \mathrm{C} / \mathrm{min}$ to $100^{\circ} \mathrm{C}$, and then heated at $5^{\circ} \mathrm{C} / \mathrm{min}$ to $240^{\circ} \mathrm{C}$ and held for $10 \mathrm{~min}$. The injection temperature was $250^{\circ} \mathrm{C}$. Helium was used as the carrier gas with flow rate of $1.0 \mathrm{ml} / \mathrm{min}$ (constant flow). Detection was carried out by mass spectrometer using ionization voltage of $70 \mathrm{eV}$. The compounds concentrations were obtained by measuring peak area from GC peaks. Identification of peaks was performed using Xcalibur data system by matching representative mass spectrum of each chromatogram peak against reference spectra in NIST library data.

\subsection{Antioxidant Activity Assay}

Antioxidant activity of the sample was determined based on the method described by Yanti et al. [16]. A $125 \mu$ of each cider was mixed with $50 \mu$ of $0.3 \mathrm{mM}$ 1,1-diphenyl-2-picryl hydrazyl (DPPH) (Sigma). Then the mixture was incubated at dark condition and room temperature for $30 \mathrm{~min}$. Subsequently, the absorbance (A) was measured with a microplate reader (Tecan) at $515 \mathrm{~nm}$. Ethanol was used as control. All samples were assayed in triplicate. The antioxidant activity was expressed as \% inhibition and calculated using the following formula:

$$
\begin{aligned}
\% \text { Inhibition }= & \frac{(A(515) \text { control }-A(515) \text { sample })}{(A(515) \text { control })} \\
& \times 100 \%
\end{aligned}
$$

\subsection{Lipase Inhibitory Assay}

Lipase inhibitory activity assay was determined using the modified method of McDougall et al. [17]. Lipase from porcine pancreas Type II (Sigma) was dissolved in ultra-pure water at $1 \mathrm{mg} / \mathrm{ml}$; then the supernatant was used after centrifugation at $7800 \mathrm{rpm}$ for $15 \mathrm{~min}$. The assay buffer was $100 \mathrm{mM}$ Tris buffer $\mathrm{pH} 8.2$ and $\mathrm{p}$ nitrophenyl butyrate (pNP butyrate; Sigma) was used as the substrate. The substrate stock $10.08 \% \mathrm{pNP}$ butyrate) was dissolved in $5 \mathrm{mM}$ sodium acetate $\mathrm{pH}$ 5.0 containing $1 \%$ Triton $\mathrm{X}-100$ and heated in boiling water for $1 \mathrm{~min}$ to aid dissolution, followed by cooling at room temperature. Control consisted of $80 \mu \mathrm{l}$ assay buffer, $30 \mu \mathrm{l}$ lipase, and $90 \mu \mathrm{l}$ substrate solution. A 10 $\mu l$ of cider was added into the mixture of buffer and enzyme, followed by the addition of substrate to start the reaction. The solution was incubated at $37^{\circ} \mathrm{C}$ for $2 \mathrm{~h}$ and read at $405 \mathrm{~nm}$ using a microplate reader. All samples were assayed in triplicate. Blank contained the assay buffer was also prepared for this assay. The result was expressed as \% inhibition of lipase and calculated using the following formula:

$$
\% \text { Inhibition }=\frac{(A(405) \text { control }-A(405) \text { sample })}{(A(405) \text { control })}
$$

2.6 Alpha-Glucosidase and Alpha-Amylase Inhibitory Assays

The a-glucosidase and a-amylase inhibitory assays were performed based on Agustinah et al. with a slight modification [18]. The a-glucosidase inhibitory assay was done by mixing $50 \mu \mathrm{l}$ of cider and $100 \mu \mathrm{l}$ of $0.1 \mathrm{M}$ phosphate buffer ( $\mathrm{pH}$ 6.9) containing $0.5 \mathrm{U} / \mathrm{ml}$ a-glucosidase enzyme (Sigma) solution in a 96-well plate. The mixture was incubated at $25^{\circ} \mathrm{C}$ for $10 \mathrm{~min}$. After pre-incubation, $50 \mu \mathrm{l}$ of substrate containing 5 mM p-nitrophenyl-a-D-glucopyranoside (Sigma) solution in $0.1 \mathrm{M}$ phosphate buffer $(\mathrm{pH}$ 6.9) was added into each well. The reaction mixture was incubated at $25^{\circ} \mathrm{C}$ for $5 \mathrm{~min}$. Before and after the 5 min incubation, the absorbance was recorded at 405 $\mathrm{nm}$ using a microplate reader. The difference between 0 - and 5 -min measurement were noted as $\triangle \mathrm{A}$. Control containing $50 \mu \mathrm{l}$ buffer solution was prepared for this assay. All ciders were assayed in triplicate. The result was expressed as \% inhibition of a-glucosidase and calculated using the following formula:

$$
\begin{aligned}
\% \text { Inhibition }= & \frac{(\Delta A(405) \text { control }-\Delta A(405) \text { sample })}{(\Delta A(405) \text { control })} \\
& \times 100 \%
\end{aligned}
$$

The a-amylase inhibitory assay was done by mixing $100 \mu \mathrm{l}$ of sample and $100 \mu \mathrm{l}$ of $0.02 \mathrm{M}$ sodium phosphate buffer $(\mathrm{pH} 6.9$ with $0.006 \mathrm{M}$ sodium chloride) containing a-amylase enzyme (MP Biomedicals) solution $(0.1 \mathrm{mg} / \mathrm{ml})$. The mixture was incubated at $25^{\circ} \mathrm{C}$ for $10 \mathrm{~min}$. After pre-incubation, 
$100 \mu \mathrm{l}$ of $1 \%(\mathrm{w} / \mathrm{v})$ starch solution in $0.02 \mathrm{M}$ sodium phosphate buffer was added to each tube and incubated at $25^{\circ} \mathrm{C}$ for $10 \mathrm{~min}$. The reaction was stopped with the addition of $200 \mu$ dinitrosalicylic acid color reagent. The test tubes were then incubated in a boiling water bath for $10 \mathrm{~min}$ and then cooled down to room temperature. The mixture was then diluted with $2 \mathrm{ml}$ of distilled water and the absorbance was measured at $540 \mathrm{~nm}$ using a spectrophotometer. The result was expressed as \% inhibition of a-amylase and calculated using the following formula:

$$
\begin{aligned}
\% \text { Inhibition }= & \frac{(A(540) \text { control }-A(540) \text { sample })}{(A(540) \text { control })} \\
& \times 100 \%
\end{aligned}
$$

\subsection{Angiotensin-Converting Enzyme Inhibitory Assays}

The angiotensin-converting enzyme (ACE) inhibitory assay was performed based on Agustinah et al. and Rumiyati et al. with modifications [18, 19]. The assay was done by mixing $50 \mu \mathrm{l}$ of cider and $200 \mu \mathrm{l}$ of $0.1 \mathrm{M}$ $\mathrm{NaCl}$ borate buffer (pH 8.3) containing $2.0 \mathrm{mU}$ ACE-I (Sigma) solution, followed by incubation at $25^{\circ} \mathrm{C}$ for $10 \mathrm{~min}$. After the incubation, $100 \mu \mathrm{l}$ of $5 \mathrm{mM}$ substrate solution (hippuryl-histidineleucine, $\mathrm{HHL}$ ) (Sigma) was added and incubated at $37^{\circ} \mathrm{C}$ for 1 hour. The reaction was stopped with the addition of $150 \mu \mathrm{l}$ of $0.5 \mathrm{~N} \mathrm{HCl}$. Hippuric acid was extracted using $1 \mathrm{ml}$ ethyl acetate and centrifuged for 10 minutes at 3500 rpm. Ethyl acetate was evaporated at $95^{\circ} \mathrm{C}$ and the residue was dissolved in $1 \mathrm{~mL}$ of distilled water. Absorbance was measured at $230 \mathrm{~nm}$ using a spectrophotometer. The result was expressed as \% inhibition of ACE and calculated using the following formula:

$$
\% \text { Inhibition }=\frac{(A(230) \text { control }-A(230) \text { sample })}{(A(230) \text { control })}
$$

\subsection{Sensory Evaluation Analysis}

The sensory evaluation was performed by 38 trained panelists using a 9-points 11: extremely dislike, 5: neither like nor dislike, 9: extremely like) hedonic scale. All samples were diluted and sweetened using the ratio of 2:5:1 for water, cider, and sugar, respectively. Samples were kept at $4^{\circ} \mathrm{C}$ until served. Each panelist tasted 5 types of samples in a blind taste test. For the organoleptic evaluation, all panelists were requested to do scoring the subjected sensory descriptors, including color, aroma, taste, aftertaste, and overall flavor profile of ciders before and after testing

\subsection{Statistical Analysis}

Data were expressed as mean \pm standard deviation (SD). Significant differences were evaluated statistically using the one-way analysis of variance (ANOVA) test, followed by Tukey's post hoc test $(p<0.05)$ of IBM SPSS Statistics version 24.0. All experiments were done in triplicate.

\subsection{RESULTS AND DISCUSSION}

\section{1 pH and Alcohol Content in Bignay Ciders}

The $\mathrm{pH}$ of each cider was measured and shown in Table 1. The $\mathrm{pH}$ recorded in this experiment ranged from 2.71 to 3.46, respectively. Ciders are not only useful as food ingredient, but also give potential health benefits. Ciders or vinegars have recently been targeted as medical foods with various health effects, including antidiabetic, antihypertension, antimicrobial, and anti-cancer activities [20, 21]. However, till present, there is no report about cider made from bignay fruits and its efficacy. Bignay fruit is naturally acidic with the $\mathrm{pH}$ range from 3.17 to 4.01 [9]. Our study revealed that both bignay juice and ciders had acidic $\mathrm{pH}$ with range from 2.71 to 3.46 (Table 1). The acidity was increased compared to bignay juice due to the fermentation by $A$. xylinum that converted sugar into organic acids [22]. Therefore, the $\mathrm{pH}$ became lower than that of bignay juice.

Table $1 \mathrm{pH}$ of various bignay ciders

\begin{tabular}{lll}
\hline \multirow{2}{*}{ Type* } & \multicolumn{2}{c}{$\mathrm{pH}$} \\
\cline { 2 - 3 } & Bignay 1\% & Bignay 5\% \\
\hline AB.3 & $2.71 \pm 0.03$ & $3.09 \pm 0.21$ \\
AB.7 & $2.75 \pm 0.02$ & $2.83 \pm 0.14$ \\
AB.14 & $2.82 \pm 0.10$ & $2.82 \pm 0.13$ \\
SC.3 & $3.41 \pm 0.14$ & $3.25 \pm 0.13$ \\
SC.7 & $3.46 \pm 0.15$ & $3.31 \pm 0.17$ \\
SC.14 & $3.35 \pm 0.07$ & $3.10 \pm 0.07$ \\
CO.7 & $3.27 \pm 0.14$ & $3.27 \pm 0.13$ \\
F & $3.23 \pm 0.05$ & $3.13 \pm 0.04$ \\
\hline *AB: Acetobacter & xylinum; SC: Saccharomyces cerevisiae; CO: \\
Combination culture (SC and AB); the ciders were fermented for 3, 7, \\
and 14 days; F: unfermented bignay juice.
\end{tabular}

Moreover, percentage of alcohol content in the bignay ciders were measured using Conway method and shown in Table 2. The highest alcohol content $(0.41 \%)$ was shown by cider fermented with $S$. cerevisiae, while the lowest one $(0.04 \%)$ was recorded on cider fermented with $A$. xylinum. Fermentation process generally produces alcohol as a results from sugar converted by yeast into alcohol. The alcohol content of the ciders in this study was ranged from $0.04 \%$ to $0.41 \%$ (Table 2). The alcohol content of commercial ciders ranged from $3 \%$ to $13 \%$ [23]. The alcohol content in bignay ciders was found to be lower than commercial ciders. It is due to facultative anaerobe fermentation in bignay ciders, therefore, the alcohol might be evaporated during the fermentation. The alcohol content of bignay ciders were similar to 
de-alcoholized ciders that had less than $0.5 \%$ of alcohol content [24]. For these reasons, this cider type could be a promising functional beverage for commercialization and consumption in Indonesia.

Table 2 Alcohol content in bignay ciders

\begin{tabular}{lll}
\hline \multirow{2}{*}{ Type* } & \multicolumn{2}{c}{ Alcohol (\% v/v) } \\
\cline { 2 - 3 } & Bignay 1\% & Bignay 5\% \\
\hline AB.3 & 0.04 & 0.18 \\
AB.7 & 0.04 & $0.06 \pm 0.01$ \\
AB.14 & 0.06 & $0.05 \pm 0.01$ \\
SC.3 & $0.41 \pm 0.01$ & $0.41 \pm 0.02$ \\
SC.7 & 0.37 & $0.41 \pm 0.01$ \\
SC.14 & 0.05 & 0.05 \\
CO.7 & 0.27 & $0.21 \pm 0.01$ \\
F & 0 & 0 \\
\hline
\end{tabular}

*AB: Acetobacter xylinum; SC: Saccharomyces cerevisiae; CO: combination culture ( $S C$ and $A B$ ); the ciders were fermented for 3,7 , and 14 days; $F$ : unfermented bignay juice.

\subsection{Identification of Chemical Compounds in Bignay Ciders}

The GC/MS chromatograms of bignay juice and ciders were shown on Figure 1. Several compounds were found to be detected and identified in both bignay juice and ciders. Interestingly, there were various major compounds identified in all bignay ciders (Table 3). Major compounds in bignay juice were L-alanyl-Lalanine (17.28\%), L-ala-L-ala-L-ala (7.3\%), and 3aminobutanoic acid $(5.47 \%)$ (Table $3 a)$. Bignay cider fermented with $A$. xylinum contained 3-aminobutanoic acid $(10.41 \%)$ (Table 3b); while bignay cider fermented with S. cerevisiae exerted L-alanyl-L-alanine (16.35\%), sarcosine (14.35\%) and 3-aminobutanoic acid (13.29\%) for (Table 3c). Bignay cider fermented with combination culture of $S$. cerevisiae and $A$. xylinum had major acetic acid $(9.41 \%)$ (Table $3 d)$.

Major compounds in bignay juice were grouped into 2 main classes, including amino acids ( $32.3 \%)$ and organic acids ( $6.3 \%)$. Based on the amount of compounds present in bignay cider fermented with $S$. cerevisiae, we found out that there was the increase of amino acids $(\sim 44 \%)$ in this cider (Table $3 c$ ) compared to that of bignay juice (Table $3 a$ ). It is known that amino acids play important roles in human health. For example, y-aminobutyric acid (GABA) is used for the ability to lower blood pressure, and branched chain amino acids (BCAA) is needed for the ability to accelerate recovery of muscle damage.
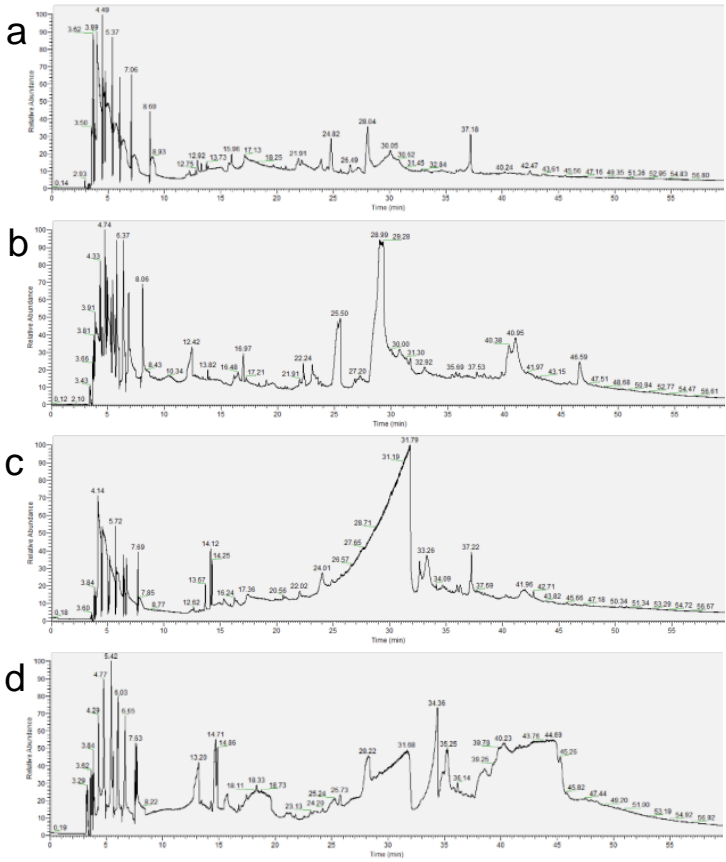

Figure 1 GC/MS chromatograms of bignay ciders. Unfermented bignay juice $5 \%$ (a); bignay cider $5 \%$ fermented with A. xylinum for 14 days (b); bignay cider $5 \%$ fermented with S. cerevisiae for 14 days (c); bignay cider $5 \%$ fermented with combination culture (S. cerevisiae and $A$. xylinum) for 7 days (d)

Table 3 Major compounds in bignay juice and ciders

\begin{tabular}{|c|c|c|c|c|c|c|}
\hline No. & Compounds Name & RT & $\begin{array}{l}\text { Molecular } \\
\text { Formula }\end{array}$ & MW & \%Area & Compound Nature \\
\hline \multicolumn{7}{|c|}{ (a) Unfermented bignay juice $5 \%$} \\
\hline 1 & L-Ala-L-Ala-L-Ala & 2.93 & $\mathrm{C}_{9} \mathrm{H}_{17} \mathrm{~N}_{3} \mathrm{O}_{4}$ & 231 & 7.3 & Amino acid \\
\hline 2 & 3-Aminobutanoic acid & 3.23 & $\mathrm{C}_{4} \mathrm{H}_{9} \mathrm{NO}_{2}$ & 103 & 5.47 & Amino acid \\
\hline 3 & L-Alanyl-L-alanine & 4.01 & $\mathrm{C}_{6} \mathrm{H}_{12} \mathrm{~N}_{2} \mathrm{O}_{3}$ & 160 & 17.28 & Amino acid \\
\hline 4 & (2-Aminothiazol-4-y) acetic acid & 4.49 & $\mathrm{C}_{5} \mathrm{H}_{6} \mathrm{~N}_{2} \mathrm{O}_{2} \mathrm{~S}$ & 158 & 1.5 & Organic acid \\
\hline 5 & Malonamic acid & 4.54 & $\mathrm{C}_{3} \mathrm{H}_{5} \mathrm{NO}_{3}$ & 103 & 5.33 & Organic acid \\
\hline 6 & D-Asparagine & 7.06 & $\mathrm{C}_{4} \mathrm{H}_{2} \mathrm{~N}_{2} \mathrm{O}_{3}$ & 132 & 0.38 & Amino acid \\
\hline 7 & L-Methionine & 37.18 & $\mathrm{C}_{5} \mathrm{H}_{11} \mathrm{NO}_{2} \mathrm{~S}$ & 149 & 1.91 & Amino acid \\
\hline \multicolumn{7}{|c|}{ (b) Bignay cider $5 \%$ fermented with A. xylinum for 14 days } \\
\hline 1 & Acefic acid & 3.43 & $\mathrm{C}_{2} \mathrm{H}_{4} \mathrm{O}_{2}$ & 60 & 0.77 & Organic acid \\
\hline 2 & L-Ala-L-Ala-L-Ala & 3.75 & $\mathrm{C}_{9} \mathrm{H}_{17} \mathrm{~N}_{3} \mathrm{O}_{4}$ & 231 & 1.1 & Amino acid \\
\hline 3 & 3-Aminobutanoic acid & 3.81 & $\mathrm{C}_{4} \mathrm{H}_{9} \mathrm{NO}_{2}$ & 103 & 10.41 & Amino acid \\
\hline 4 & 2-Phosphonoethylphosphonic acid & 27.01 & $\mathrm{C}_{2} \mathrm{H}_{8} \mathrm{O}_{8} \mathrm{P}_{2}$ & 190 & 0.52 & Organic acid \\
\hline \multicolumn{7}{|c|}{ (c) Bignay cider $5 \%$ fermented with S. cerevisiae for 14 days } \\
\hline 1 & Sarcosine & 3.54 & $\mathrm{C}_{3} \mathrm{H}_{7} \mathrm{NO}_{2}$ & 89 & 14.35 & Amino acid \\
\hline 2 & 3-Aminobutanoic acid & 3.84 & $\mathrm{C}_{4} \mathrm{H}_{9} \mathrm{NO}_{2}$ & 103 & 13.29 & Amino acid \\
\hline 3 & L-Alanyl-L-alanine & 4.55 & $\mathrm{C}_{6} \mathrm{H}_{12} \mathrm{~N}_{2} \mathrm{O}_{3}$ & 160 & 16.35 & Amino acid \\
\hline 4 & (2-Aminothiazol-4-y) acefic acid & 5.72 & $\mathrm{C}_{5} \mathrm{H}_{6} \mathrm{~N}_{2} \mathrm{O}_{2} \mathrm{~S}$ & 158 & 0.85 & Organic acid \\
\hline 5 & D-Glucosamine & 12.45 & $\mathrm{C}_{6} \mathrm{H}_{13} \mathrm{NO}_{5}$ & 179 & 0.24 & Hexose \\
\hline \multicolumn{7}{|c|}{ (d) Bignay cider $5 \%$ fermented with combination culture ( 5 . cerevisiae and A. xylinum) for 7 days } \\
\hline 1 & Acetic acid & 3.75 & $\mathrm{C}_{2} \mathrm{H}_{4} \mathrm{O}_{2}$ & 60 & 9.41 & Organicacid \\
\hline 2 & O-Acetyl-L-serine & 7.62 & $\mathrm{C}_{4} \mathrm{H}_{12} \mathrm{~N}_{2}$ & 88 & 1.17 & Amino acid \\
\hline
\end{tabular}

Some amino acids play roles as key determinants in food taste. It is also known that free amino acids are aroma precursors and utilized for the synthesis of aroma components during fruits maturation [25]. The chemical compounds in bignay cider $5 \%$ were also identified. The results in bignay cider showed increasing organic acid contents compared to the unfermented bignay juice which reach around $9 \%$ in cider fermented with combination culture (Table $3 d$ ). According to Zhang et al., the content of organic acids in fruit juices influences the $\mathrm{pH}$, flavour as well as the stability, nutritional aspects, acceptability, and keeping quality of the cider [26]. Carboxylic acids are 
important constituents in many foods, such as fresh products or fermentation products such as cider, which resulting from fermentative process. Organic acids are quality indicators during cider brewing.

\subsection{Antioxidant Activity of Bignay Ciders}

Antioxidant activity of bignay ciders ranged from $32.7 \%$ to $72.5 \%$ (Figure 2). Interestingly, the antioxidant activity of fermented bignay ciders was not significantly different compared to that of the unfermented bignay juice. Only cider made from $5 \%$ of bignay fruit concentration and fermented with combination culture was significantly different $(p<0.05)$ compared to the unfermented bignay juice at similar concentration. Oxidative stress may induce damages to cell structures, including membranes, proteins, and DNA. For these reasons, it would appear to be involved in the pathogenesis of diseases leading to metabolic syndrome [2, 27]. Therefore, antioxidant activity is important because it scavenges oxidative stress in the body and prevents metabolic syndrome. Antioxidant activity was evaluated using DPPH stable free radical method that has been widely applied due to its sensitivity and rapid way to investigate the antioxidant activity of specific compounds [11].

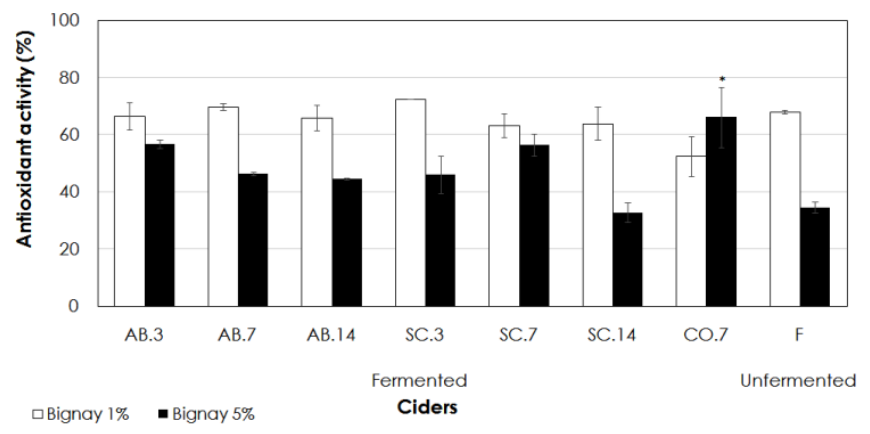

Figure 2 Antioxidant activity of various bignay ciders. $A B$ : Acetobacter xylinum; SC: Saccharomyces cerevisiae; CO: combination culture ( $S C$ and $A B$ ); the ciders were fermented for 3, 7, and 14, days; F: unfermented bignay juice. Bars with "*" indicated a statistically significant difference $(p<0.05)$ between the fermented bignay ciders and unfermented bignay juice of the same fruit ratio

As seen on Figure 2, the unfermented bignay juice exerted high scavenging activity against DPPH. These results are linear with previous studies that showed the antioxidant capacity of bignay fruits at both immature and over-ripe stages [8,9]. According to Butkhup and Samappito, high scavenging ability on DPPH free radicals might be correlated with phenolic compounds in the bignay fruit extract [11].

\subsection{Lipase Inhibitory Activity of Bignay Ciders}

Bignay ciders significantly inhibited the pancreatic lipase in vitro (Figure 3). The inhibitory activity of fermented bignay ciders was significantly higher $(p<0.05)$ compared to that of the unfermented bignay juice, except for bignay $1 \%$ fermented with $S$. cerevisiae for 14 days and for bignay $5 \%$ fermented with S. cerevisiae for 3 days. All ciders were tested against enzymes that play important roles in metabolic syndrome, such as lipase, a-glucosidase, a-amylase, and ACE. First, the ciders were tested against pancreatic lipase enzyme in vitro. Any dietary fat consumed should be broken down enzymatically by the action of pancreatic lipase before being absorbed in human intestines. Therefore, one of the promising strategies for management of obesity is to interfere with fat absorption along the gastrointestinal tract directly. This enzyme is widely considered as one of the most important indicators for determination of natural antiobesity agents [28, 29].

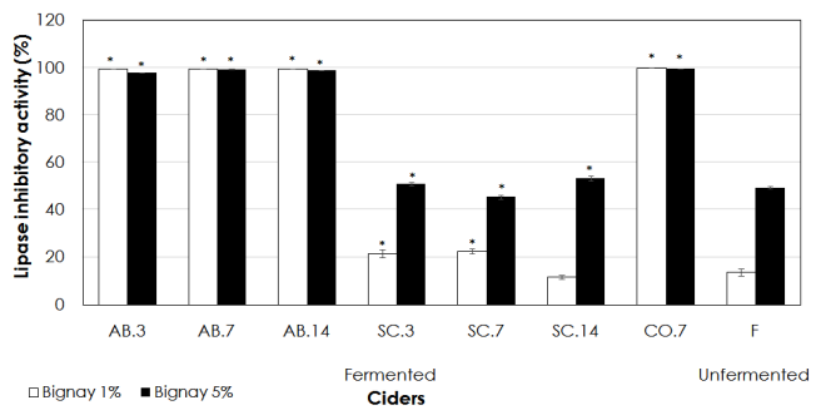

Figure 3 Lipase inhibitory activity of various bignay ciders. $A B$ : Acetobacter xylinum; SC: Saccharomyces cerevisiae; CO: combination culture ( $S C$ and $A B$ ); the ciders were fermented for 3, 7, and 14 days; F: unfermented bignay juice. Bars with "*" indicated a statistically significant difference $(p<0.05)$ between the fermented bignay ciders and unfermented bignay juice of the same fruit ratio

Our results showed that most ciders effectively inhibited pancreatic lipase (Figure 3), indicating their potency as antiobesity candidates for protection against metabolic syndrome. Previous study has been reported that naturally-occurring polyphenols inhibited pancreatic lipase and thereby influenced fat digestion and affected the energy intake [30]. The suppression of energy intake was shown by inhibiting the action of pancreatic lipase [17]. Acetic acid, which is the major ingredient in vinegar, is considered to be an active ingredient that may affect body fat reduction and body weight gain. Moreover, it has been reported to be a potential agent for preventing metabolic syndrome by reducing obesity in rats and even obese human subjects $[20,21]$.

\subsection{Alpha-glucosidase and Alpha-amylase} Inhibitory Activities of Bignay Ciders

Bignay ciders also had high a-glucosidase inhibitory activity, especially in ciders fermented with A. xylinum and ciders fermented with combination culture(Figure 4). The difference between fermented bignay ciders and unfermented bignay juice was significant $(\mathrm{p}<0.05)$, except for bignay cider $5 \%$ fermented with $S$. 
cerevisiae for 14 days. Despite their potential inhibitory activity against a-glucosidase, bignay ciders did not inhibit the a-amylase enzyme (data not shown). Only bignay $5 \%$ fermented with $A$. xylinum for 14 days had the inhibitory activity $>50 \%$ against a-amylase enzyme.

It is noted that the inhibition of a-glucosidase and a-amylase that involved in carbohydrate digestion significantly reduced the post-prandial increase of blood glucose [31]. Therefore, inhibitory enzymatic assay of a-glucosidase and a-amylase in vitro could be applied as a model to investigate the potency of sample for management of blood glucose level in diabetic patients. The bignay cider had high inhibitory activity against a-glucosidase with $>90 \%$ (Figure 4), especially for ciders fermented with $A$. xylinum. The inhibition pattern of most ciders were significantly different compared to that of the unfermented bignay juice. However, these results could not compared to other previous studies because this the first study to formulate the cider beverages from bignay fruits and test their efficacy against a-glucosidase inhibitory activity. Previous related studies demonstrated that the bignay leaves and fruits exerted a-glucosidase inhibitory activity $[32,33]$.

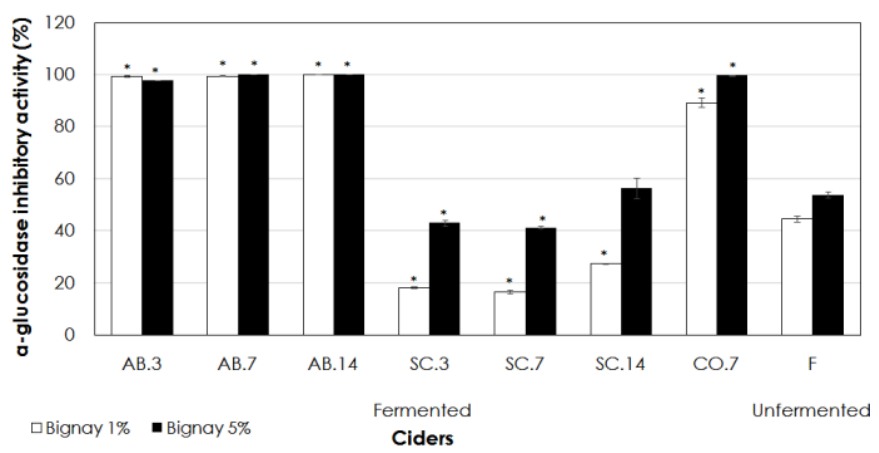

Figure 4 Alpha-glucosidase inhibitory activity of various bignay ciders. AB: Acetobacter xylinum; SC: Saccharomyces cerevisiae; $C O$ : combination culture ( $S C$ and $A B$ ); the ciders were fermented for 3, 7, and 14 days; F: unfermented bignay juice. Bars with "*" indicated a statistically significant difference $(p<0.05)$ between the fermented and unfermented of the same fruit ratio

Furthermore, bignay ciders were also tested for its inhibitory activity against the a-amylase enzyme. Among all bignay ciders, only bignay cider $5 \%$ fermented with $A$. xylinum for 14 days had the potency to inhibit $>50 \%$ of a-amylase (data not shown). Moreover, it is shown that bignay ciders were more sensitive towards the a-glucosidase pathway than the a-amylase one. Inhibition toward glucose uptake enzymes was influenced by the individual and specific phenolic compounds, structure, and interaction [18]. These results suggest that bignay ciders may have potency as antidiabetic candidates through their ability to inhibit a-glucosidase as one of a glucose uptake enzymes that lead to the decrease of blood glucose level.

\subsection{Angiotensin-Converting Enzyme Inhibitory Activity of Bignay Ciders}

The bignay ciders were tested against ACE. In vitro enzymatic inhibitory activity against ACE has been used as a model to study the potential capacity of phenolic compounds to reduce high blood pressure [18]. The results showed that all bignay ciders had low inhibitory activity $(<5 \%)$ toward ACE (Figure 5), indicating that these ciders was less effective for management of hypertension. However, this results were contradictory with previous study which reported that bignay fruit extract had the ability to lower blood pressure [8]. This study needs further optimization to formulate certain amounts of bignay cider that could give the ability to reduce high blood pressure via inhibiting ACE.

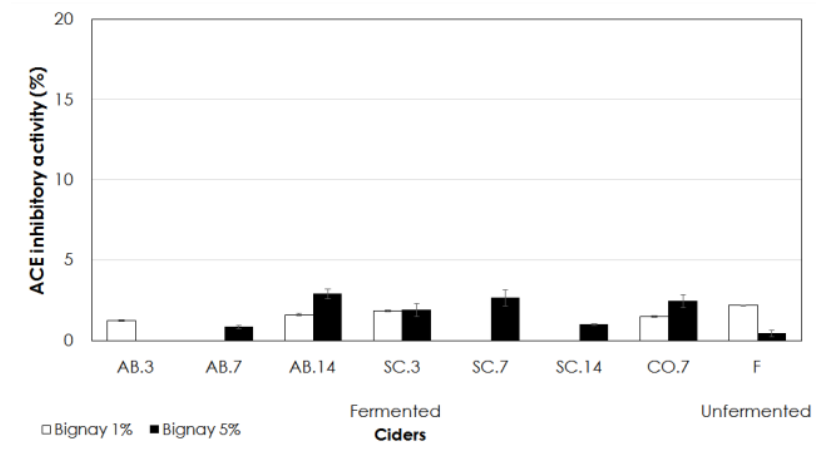

Figure 5 ACE inhibitory activity of various bignay ciders. $A B$ : Acetobacter xylinum; SC: Saccharomyces cerevisiae; CO: combination culture ( $S C$ and $A B$ ); the ciders were fermented for 3, 7, and 14 days; F: unfermented bignay juice

\subsection{Sensory Evaluation of Bignay Ciders}

The bignay ciders were subjected for the sensory evaluation using hedonic scale from 1 (extremely dislike) to 9 (extremely like) (Figure 6) These results showed that bignay juice and bignay ciders were more likable compared to that of commercial cider. The bignay cider $5 \%$ fermented with A. xylinum for 14 days had highest evaluation with 6.7 among other ciders (Table 4).

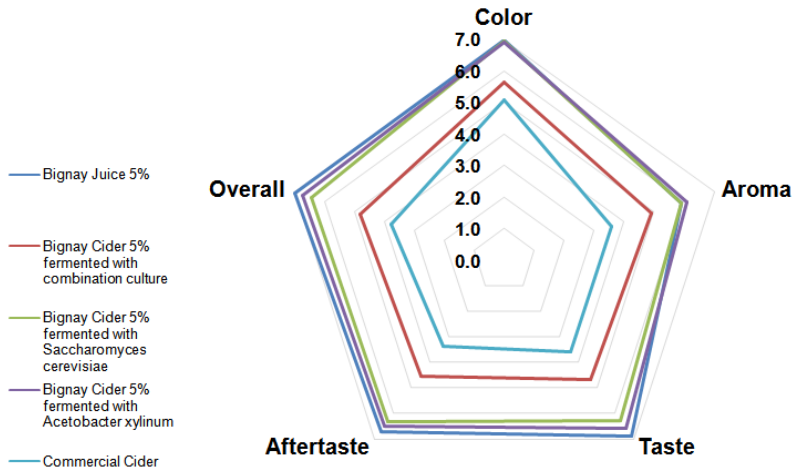

Figure 6 Spider chart of sensory evaluation of bignay ciders 
Table 4 Sensory evaluation of bignay ciders

\begin{tabular}{cccccc}
\hline Cider* & Color & Aroma & Taste & $\begin{array}{c}\text { Aftertas } \\
\text { te }\end{array}$ & Overall \\
\hline AB.14 & $6.9 \pm 0.9$ & $6.1 \pm 1.3$ & $6.6 \pm 1.5$ & $6.4 \pm 1.5$ & $6.7 \pm 1.3$ \\
SC.14 & $6.9 \pm 0.9$ & $5.9 \pm 1.4$ & $6.3 \pm 1.3$ & $6.3 \pm 1.2$ & $6.4 \pm 1.2$ \\
CO.7 & $5.7 \pm 1.6$ & $4.9 \pm 1.7$ & $4.6 \pm 2.1$ & $4.5 \pm 2.2$ & $4.8 \pm 1.9$ \\
F & $7.0 \pm 0.8$ & $5.9 \pm 1.1$ & $6.9 \pm 1.2$ & $6.7 \pm 1.0$ & $7.0 \pm 1.1$ \\
F & $7.0 \pm 0.8$ & $5.9 \pm 1.1$ & $6.9 \pm 1.2$ & $6.7 \pm 1.0$ & $7.0 \pm 1.1$
\end{tabular}

*AB.14: $5 \%$ bignay cider fermented with Acetobacter xylinum for 14 days; SC.14: $5 \%$ bignay cider fermented with Saccharomyces cerevisiae for 14 days; C0.7: $5 \%$ bignay cider fermented with combination culture (A. xylinum and S. cerevisiae) for 7 days; F: unfermented bignay juice 5\%; C: commercial apple cider

Sensory evaluation of the ciders was done using 9point hedonic scale by 38 trained panelists. The ciders which subjected to sensory evaluation were bignay juice $5 \%$, bignay cider $5 \%$ fermented with combination culture for 7 days, bignay cider $5 \%$ fermented with $S$. cerevisiae for 14 days, bignay cider $5 \%$ fermented with A. xylinum for 14 days, and commercial apple cider. All samples used in this evaluation were diluted and sweetened using water, cider, and sugar with ratio of 2:5:1, respectively. Sensory evaluation showed that bignay juice $5 \%$ was preferred compared to others because of the taste property which was sweeter compared to ciders (Figure 6 and Table 4).

While, among all ciders, bignay cider $5 \%$ fermented with A. xylinum for 14 days had the best sensory evaluation because it had bright red color which was attractive and the best taste compared to other ciders. Based on the overall sensory evaluation, bignay juice $5 \%$ is preferable compared to bignay ciders. Therefore, prior to its potency as a novel functional dietary source against metabolic syndrome protection, ciders made from bignay fruits are still needed further formulation for obtaining the optimal results of overall flavor composition.

\subsection{CONCLUSION}

These data demonstrated that ciders made from bignay fruits exerted potential antioxidant activity and high enzymatic inhibitory activity against lipase and alpha-glucosidase. In brief, bignay ciders may be applied as functional beverages for protection against metabolic syndrome.

\section{Acknowledgement}

This research was fully funded by the 2019 Faculty Grant from Institute for Research and Community Service, Atma Jaya Catholic University of Indonesia, Jakarta (Indonesia).

\section{References}

[1] Alberti, K. G., P. Zimmet, and J. Shaw. 2005. The Metabolic Syndrome - A New Worldwide Definition. Lancet. 366(9491): 1059-1062.

DOI: http://dx.doi.org/10.1016/S0140-6736(05)67402-8.

[2] Marseglia, L., S. Manti, G. D'Angelo, A. Nicotera, E. Parisi, G. Di Rosa, E. Gitto, and T. Arrigo. 2015. Oxidative Stress in Obesity: A Critical Component in Human Diseases. International Journal of Molecular Sciences. 16(1): 378400.

DOI: http://dx.doi.org/10.3390/ijms16010378.

[3] World Health Organization (WHO). 2018. Obesity and Overweight. Retrieved on February 24, 2019 from WHO Website:http://www.who.int/mediacentre/factsheets/fs31 1/en/.

[4] Esser, N., S. Legrand-Poels, J. Piette, A. J. Scheen, and N. Paquot. 2014. Inflammation as A Link Between Obesity, Metabolic Syndrome and Type 2 Diabetes. Diabetes Research and Clinical Practice. 105(2): 141-150. DOI: http://dx.doi.org/ 10.1016/j.diabres.2014.04.006.

[5] Yanai, H., Y. Tomono, K. Ito, N. Furutani, H. Yoshida, and N. Tada. 2008. The Underlying Mechanisms for Development of Hypertension in the Metabolic Syndrome. Nutrition Journal. 7: 10

DOI: http://dx.doi.org/ 10.1186/1475-2891-7-10

[6] Budak, N. H., E. Aykin, A. C. Seydim, A. K. Greene, and Z. B. Guzel-Seydim. 2014. Functional Properties of Vinegar. Journal of Food Science. 79(5): R757-R764.

DOI: http://dx.doi.org/10.1111/1750-3841.12434.

[7] Butkhup, L., and S. Samappito. 2011. Phenolic Constituents of Extract from Mao Luang Seeds and Skin-Pulp Residue and Its Antiradical and Antimicrobial Capacities. Journa of Food Biochemistry. 35(6): 1671-1679.

DOI: http://dx.doi.org/10.1111/j.1745-4514.2010.00491.x.

[8] Lim, T. K. 2012. Antidesma bunius. In Lim, T. K. (ed.). Edible Medicinal and Non Medicinal Plants. Vol. 4. Dordrecht: Springer Netherlands. 220-223.

DOI : http://dx.doi.org/10.1007/978-94-007-2534-8

[9] Castillo-Israel, K. A. T., K. J. D. Sartagoda, M. C. R. llano, L. E. L. Flandez, M. C. M. Compendio, and D. B. Morales. 2020. Antioxidant Properties of Philippine Bignay (Antidesma bunius (Linn.) Spreng cv. 'Common') Flesh and Seeds as Affected by Fruit Maturity and Heat Treatment. Food Research. 4(6): 1980-1987.

[10] Belmi R. M., J. Giron, and M. L. Tansengco. 2014 Antidesma bunius (bignay) Fruit Extract as an Organic Pesticide against Epilachna spp. Journal of Asian Scientific Research. 4(7): 320-327.

[11] Butkhup, L., and S. Samappito S. 2008. Analysis of Anthocyanin, Flavonoids, and Phenolic Acids in Tropical Bignay Berries. International Journal of Fruit Science. 8(1-2): 15-34.

DOI: http://dx.doi.org/10.1080/15538360802365913.

[12] Islam, Md., S., Md. S. Ahammed, F. I. Sukorno, S. F. Koly, Md. M. Biswas, and S. Hossain. 2018. A Review on Phytochemical and Pharmacological Potentials of Antidesma bunius. Journal of Analytical \& Pharmaceutical Research. 7(5): 602-604. DOI: http://dx.doi.org/10.15406/japlr.2018.07.00289.

[13] Kaye, S. 1980. A Rapid Screening Blood Alcohol Analysis for The Local Pathologist. The American Journal of Forensic Medicine and Pathology. 1 (XX): 205-208.

DOI: http://dx.doi.org/10.1097/00000433-198009000-00002.

[14] Oktaviani, S. D., Sabikis, and D. Hartanti. 2011 Identification of Ethanol Fermented from Sente (Alocasia macrorrizha (L.) g. don), Sente Wulung (Alocasia indica (Lour.) Koch) and Kimpul (Xhantosoma nigrum (Vell.) Mansf). Pharmaceutical Journal of Indonesia. 8(1): 25-43. DOI: http://dx.doi.org/10.30595/pji.v8i1.594.

[15] Chinnici, F., E. D. Guerrero, F. Sonni, N. Natali, R. N. Marín and C. Riponi. 2009. Gas Chromatography-Mass Spectrometry (GC-MS) Characterization of Volatile 
Compounds in Quality Vinegars with Protected European Geographical Indication. Journal of Agricultural and Food Chemistry. 57(11): 4784-4792.

DOI: http://dx.doi.org/10.1021/jf804005w.

[16] Yanti, Veronica, and B. W. Lay. 2017. Bioactive Crude Extracts from Several Psychrobacter alimentarius Isolated from Indonesian Coastal Sediment. Scholar Academic Journal of Biosciences. 5(9): 631-637.

[17] McDougall, G. J., N. N. Kulkarni, and D. Stewart. 2009. Berry Polyphenols Inhibit Pancreatic Lipase Activity In Vitro. Food Chemistry. 115(1):193-199. DOI: http://dx.doi.org/10.1016/j.foodchem.2008.11.093.

[18] Agustinah, W., D. Sarkar, F. Woods, and K. Shetty. 2016. Apple and Blueberry Synergies for Designing Bioactive Ingredients for the Management of Early Stages of Type 2 Diabetes. Journal of Food Quality. 39(4): 370-382. DOI: http://dx.doi.org/10.1111/jfq.12206.

[19] Rumiyati, Sudarsono, B. O. Susanto, S. K. Mayasari, and R. N. Wijaya. 2016. In Vitro ACE Inhibitory Assay of Extracts Containing Flavonoid-Phenolic Compounds of Edible Plants. International Journal of Pharmaceutical and Clinical Research. 8(5): S414-S418.

[20] Beh, B. K, N. E. Mohamad, S. K. Yeap, H. Ky, S. Y. Boo, J. Y. H. Chua, S. W. Tan, W. Y. Ho, S. A. Sharifuddin, K. Long, and N. B. Alitheen. 2017. Anti-Obesity and Anti-Inflammatory Effects of Synthetic Acetic Acid Vinegar and Nipa Vinegar on High-Fat-Diet-Induced Obese Mice. Scientific Reports. 7(1): 6664. DOI: http://dx.doi.org/10.1038/s41598-01706235-7

[21] Halima, B. H., G. Sonia, K. Sarra, B. J. Houda, B. S. Fethi, and A. Abdallah. 2018. Apple Cider Vinegar Attenuates Oxidative Stress and Reduces the Risk of Obesity in HighFat-Fed Male Wistar Rats. Journal of Medicinal Food. 21 (1): 70-80.

DOI: http://dx.doi.org/ 10.1089/jmf.2017.0039.

[22] Mamlouk, D., and M. Gullo. 2013. Acetic Acid Bacteria: Physiology and Carbon Sources Oxidation. Indian Journal of Microbiology. 53(4): 377-384.

DOI: http://dx.doi.org/10.1007/s12088-013-0414-z.

[23] Dunn, D., G. Awdey, and C. McGonegal. 2015. Specialty Cider and Perry. In Strong G. and K. England K (eds.). 2015 Style Guideline: Cider Style Guidelines. St. Louis: Beer Judge Certification Program.

[24] Jarvis, B. 2014. Cider (Cyder; Hard Cider). Encyclopedia Food Microbiology. 2014: 437-443.

DOI: http://dx.doi.org/10.1016/B978-0-12-384730-0.00066-5.
[25] Ito, H., H. Ueno, and H. Kikuzaki. 2017. Free Amino Acid Compositions for Fruits. Journal of Nutrition and Dietetic Practice. 1(1): 1-5.

[26] Zhang, H., F. Zhou, B. Ji, R. M. J. Nout, Q. Fang, and Z. Yang. 2008. Determination of Organic Acids Evolution During Apple Cider Fermentation Using An Improved HPLC Analysis Method. European Food Research and Technology. 227: 1183-1190.

DOI: http://dx.doi.org/10.1007/s00217-008-0835-9.

[27] Matsuda, M., and I. Shimomura. 2013. Increased Oxidative Stress in Obesity: Implications for Metabolic Syndrome, Diabetes, Hypertension, Dyslipidemia, Atherosclerosis, and Cancer. Obesity Research and Clinical Practice. 7(5): e330-341.

DOI: http://dx.doi.org/10.1016/j.orcp.2013.05.004.

[28] Marrelli, M., M. R. Loizzo, M. Nicoletti, F. Menichini, and F. Conforti. 2013. Inhibition of Key Enzymes Linked to Obesity by Preparations from Mediterranean Dietary Plants: Effects on a-Amylase and Pancreatic Lipase Activities. Plant Foods for Human Nutrition. 68(4): 340-346.

DOI : http://dx.doi.org/10.1007/s1 1130-013-0390-9.

[29] Sun, N. N., T. Y. Wu, and C. F. Chau. 2016. Natural Dietary and Herbal Products in Anti-Obesity Treatment. Molecules. $21(10): 1351$

DOI: http://dx.doi.org/10.3390/molecules21101351.

[30] McDougall, G. J., and D. Stewart. 2005. The Inhibitory Effects of Berry Polyphenols on Digestive Enzymes. Biofactors. 23(4): 189-195.

DOI: http://dx.doi.org/10.1002/biof.5520230403.

[31] Tundis R, Loizzo MR, Menichini F. 2010. Natural Products as a-Amylase and;a-Glucosidase Inhibitors and their Hypoglycaemic Potential in the Treatment of Diabetes: An Update. Mini-Reviews in Medicinal Chemistry. 10(4): 315331. DOI: http://dx.doi.org/10.2174/138955710791331007.

[32] Lawag IL, Aguinaldo AM, Naheed S, Mosihuzzaman M. 2012. a-Glucosidase Inhibitory Activity of Selected Philippine Plants. Journal of Ethnopharmacology. 144(1): 217-219.

DOI: http://dx.doi.org/ 10.1016/j.jep.2012.08.019.

[33] Quiming N, Asis JL, Nicolas M, Versoza D, Alvarez MR. 2016. In Vitro a-Glucosidase Inhibition and Antioxidant Activities of Partially Purified Antidesma bunius Fruit and Gynura nepalensis Leaf Extracts. Journal of Applied Pharmaceutical Science. 6(5): 97-101. DOI: http://dx.doi.org/10.7324/japs.2016.60515. 